Article

\title{
Enhanced Nitrogen and Phosphorus Removal by Woody Plants with Deep-Planting Technique for the Potential Environmental Management of Carcass Burial Sites
}

\author{
Byoung-Hwan Seo ${ }^{1}$, Hyuck Soo Kim ${ }^{2}$, Saranya Kuppusamy ${ }^{3}$, Kye-Hoon Kim ${ }^{4}$ and \\ Kwon-Rae Kim ${ }^{1, *}$ \\ 1 Department of Agronomy and Medicinal Plant Resources, Gyeongnam National University of Science \\ and Technology, Jinju 660-758, Korea; sbhsbhlove@naver.com \\ 2 Department of Biological Environment, Kangwon National University, Chuncheon-si, Gangwon-do 24341, \\ Korea; khs25@kangwon.ac.kr \\ 3 Institute of Agriculture and Life Science, Gyeongsang National University, Jinju 52828, Korea; \\ kuppusamy.saranya@gmail.com \\ 4 Department of Environmental Horticulture, University of Seoul, Seoul 130-743, Korea; johnkim@uos.ac.kr \\ * Correspondence: kimkr419@gntech.ac.kr; Tel.: +82-55-751-3223; Fax: +82-55-751-3229
}

Academic Editors: Geonha Kim, Daniel C. W. Tsang, Zeng-Yei Hseu, Chaeyoung Lee, Meththika Vithanage and Yong Sik Ok

Received: 30 November 2016; Accepted: 12 January 2017; Published: 20 January 2017

\begin{abstract}
Phytoremediation is a promising technology to remediate carcass burial sites where deep soil layers are contaminated with nitrogen $(\mathrm{N})$, phosphorus $(\mathrm{P})$ and other potential contaminants by leachate. The current study was conducted to examine the remedial efficiency of two different woody plants, poplar (Populus euramericana) and willow (Salix alba), by employing the deep-planting technique for the enhanced removal of $\mathrm{N}$ and $\mathrm{P}$ for the soil affected by leachate. For this, pot trials to assess $\mathrm{N}$ and $\mathrm{P}$ removal efficiency of poplar and willow in liquid manure-applied soil, and pilot-scale column experiments to evaluate the suitability of the deep-planting technique for the enhanced phytoremediation of deep soil layer were conducted. The results of this study showed that poplar and willow removed $\mathrm{N}$ and $\mathrm{P}$ from soils effectively while surviving under deep-planting conditions. Notably, compared to the surface planted roots, the roots of the deep-planted poplar and willow could transfer significant amounts of $\mathrm{N}$ and $\mathrm{P}$ leachate from the deep soil layer to the rhizosphere, from where it can be absorbed by the plants. For the first time, the use of poplar or willow plants are recommended by employing the deep-planting technique for the successful remediation of carcass burial sites.
\end{abstract}

Keywords: phytoremediation; deep-planting technique; poplar; willow; leachate; liquid manure

\section{Introduction}

In Korea, during the foot-and-mouth disease (FMD) outbreak from November 2010 to April 2011, about 10,000 cattle and 340,000 pigs were disposed into 4500 sites around the country [1]. Due to the putrefaction of buried animals, contaminated leachate containing a wide range of contaminants such as nitrogen $(\mathrm{N})$ and phosphorous $(\mathrm{P})$ originating from the carcass burial sites can be released into nearby soil and water bodies [2]. For example, Kim et al. [3] reported that some of the soil samples collected around the animal carcass disposal sites showed higher electrical conductivity (EC), $\mathrm{NH}_{4}-\mathrm{N}$, and $\mathrm{NO}_{3}-\mathrm{N}$ concentration compared to those of the background soils. Especially, the concentration of $\mathrm{NH}_{4}-\mathrm{N}$ in a soil sample $\left(87.6 \mathrm{mg} \cdot \mathrm{kg}^{-1}\right)$ collected around the burial site was approximately 80 times higher than that in the background soil $\left(1.1 \mathrm{mg} \cdot \mathrm{kg}^{-1}\right)$. 
A suitable remediation technique is required to remove the leachate and make the carcass burial sites suitable for re-utilization by humans. Also, remediation technology must be carefully chosen to minimize the impact on other agricultural fields since many burial sites are located in and around agricultural areas. Among the available remediation technologies, phytoremediation is most appropriate for the removal of contaminants from leachate in carcass burial sites. Phytoremediation is a technology that involves the use of plants to remove inorganic and/or organic contaminants from the environment, where plants could successfully remediate contaminants by means of adsorption, transportation and translocation, hyper-accumulation, or transformation and mineralization processes [4-6]. Also, phytoremediation is a cost effective, promising and environmentally friendly technology [7]. Among various plant species used for phytoremediation, the focus has been recently to research endophytes within the poplar and willow species since they grow rapidly, have many roots and produce high biomass [8-10]. So far, poplar and willow have been used successfully for the phytoremediation of various contaminated sites [11-15]. For example, poplar and willow planted on heavy metals-contaminated sites in the north of France accumulate Cd in the range from 13 to $44 \mathrm{mg} \cdot \mathrm{kg}^{-1}$ (dry weight) in leaves and from 9 to $15 \mathrm{mg} \cdot \mathrm{kg}^{-1}$ in stems, and these $\mathrm{Cd}$ concentrations are significantly higher than in the other species investigated (oak and birch) [14].

It is important to note that the success of phytoremediation may be limited by factors such as growing time, climate, root depth, soil chemistry and level of contamination [16], and the prime factor that limits the phytoremediation applicability is root contact [17]. Generally, contaminants released from carcass burial sites are located predominantly in the deep layers and this limits the success of the typical phytoremediation technique. In Korea, according to the environmental management guideline of carcasses burial sites, the carcasses should be placed in the pit at least at a depth of two meters from the surface of the ground [2]. For that reason, roots of plants used for phytoremediation of carcass burial sites must be able to reach deep layers. One option is to use the deep-planting technology-planting of long-stem nursery stock whose root crowns are deeply buried. Previously the US Department of Agriculture (USDA) has been using the deep-planting technique for revegetation [18]. They reported that deep-planting of long-stem stock can drastically reduce the need to irrigate in order to establish the riparian shrubs and trees, because roots are in contact with the capillary fringe [18]. However, they applied this concept for restoring ecosystem function in degraded riparian zones through the deep-planting of long-stem nursery stock to take advantage of water at the capillary fringe. To the best of our knowledge, so far the deep-planting technique has not been used in the phytoremediation of carcass burial sites.

With the above focus, the current study was carried out to examine the phytoremedial efficiency of two different woody plants including poplar and willow for $\mathrm{N}$ and $\mathrm{P}$ leachate removal from manure-applied soil. Furthermore since $\mathrm{N}$ and $\mathrm{P}$ released from contaminated plume are usually located deep in the soil, this study investigated the applicability of the deep-planting technique with guard column for the significant reduction of $\mathrm{N}$ and $\mathrm{P}$ leachate levels in manure-applied deep soil layer. In order to substitute the contaminated leachate containing $\mathrm{N}$ and $\mathrm{P}$ originated from the carcass burial sites, liquid manure (LM) collected from local liquid manure facilities was used in this study.

\section{Materials and Methods}

\subsection{Soil and Liquid Manure}

The soil samples used for both the pot and the pilot-scale studies were collected from the upland field located on the experimental farm of Gyeongnam National University of Science and Technology (GNTECH), South Korea. The collected soil characteristics were as follows: $\mathrm{pH}, 7.61$; EC, $0.1 \mathrm{dS} \cdot \mathrm{m}^{-1}$; total nitrogen $(\mathrm{N}), 1.0 \mathrm{~g} \cdot \mathrm{kg}^{-1}$; total phosphorus $(\mathrm{P}), 0.9 \mathrm{~g} \cdot \mathrm{kg}^{-1}$. Liquid manure was made of pig manure by aeration for 40 days. 


\subsection{Pot Trial}

Sixty-liter pots were filled with $40 \mathrm{~kg}$ prepared soil followed by transplanting one-year-old poplar (Populus euramericana) and willow (Salix alba) seedlings. To compare removal efficiencies of $\mathrm{N}$ and P by woody plants, no woody plant pots (control) were also prepared in the same manner. Poplar and willow were subsequently cultivated from May 2012 to December 2013 under natural conditions and then harvested for the assessment of poplar and willow efficiency for the phytoremediation of soils affected by contaminated plumes (Figure 1). During cultivation, three different experimental treatments were applied by irrigating three different liquids as contaminated or non-contaminated plumes. These included full strength (1S) LM (N: $2000 \mathrm{mg} \cdot \mathrm{L}^{-1}$; P: $\left.450 \mathrm{mg} \cdot \mathrm{L}^{-1}\right), 1 / 2$ strength $(1 / 2 \mathrm{~S}) \mathrm{LM}$ (liquid manure:tap water $=1: 1$ ), and tap water. In 2012, the prepared liquids (50 L) were supplied to the pot soil from the bottom at 3 times between August and September. Also, in 2013, liquids (84 L) were supplied between May and July in the same way. During this experiment, on a daily basis, decreases in volume of the liquids were monitored to estimate the amounts of applied $\mathrm{N}$ and $\mathrm{P}$ in liquids for each pot, and removal amounts for $\mathrm{N}$ and $\mathrm{P}$ in soils by woody plants were estimated by subtracting the contents of $\mathrm{N}$ and $\mathrm{P}$ in soil at the end of experiment from the added amount of $\mathrm{N}$ and $\mathrm{P}$ through liquid manures. The initial $\mathrm{N}$ and $\mathrm{P}$ contents in soils were considered for this calculation. Soils used in the pot trial were collected each year in December for analysis and leaves and branches of woody plants were also collected after cultivation.

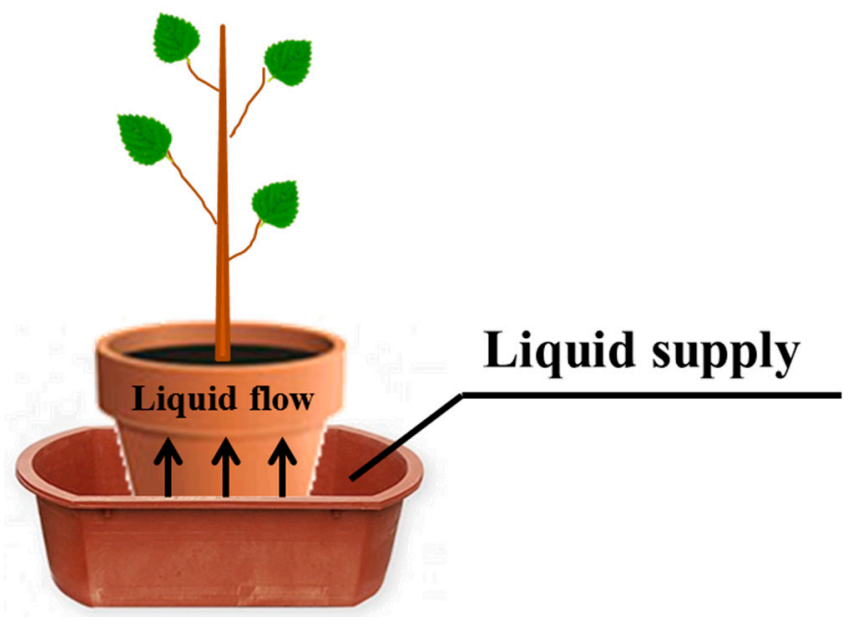

Figure 1. Experimental scheme of the pot experiment.

\subsection{Pilot-Scale Column Experiment}

The pilot-scale column experiments were conducted under natural conditions during 21 months (from April 2013 to December 2014). The pilot-scale columns were fabricated from PVC (50 cm inner diameter and $200 \mathrm{~cm}$ height) and they were filled from bottom to top with $0.2 \mathrm{~m}$ of gravel and $1.7 \mathrm{~m}$ of prepared soil. In order to investigate the change in $\mathrm{N}$ and $\mathrm{P}$ contents in soils by woody plants, two soil sampling holes ( $4 \mathrm{~cm}$ inner diameter) on the side at $1 \mathrm{~m}$ and $1.5 \mathrm{~m}$ from the top of the column were set. An endoscope equipped with camera was also used at $1.5 \mathrm{~m}$ depth to observe the growth of the woody plant roots. Both poplar and willow were transplanted at $1 \mathrm{~m}$ depth in soils with PVC guard column (Figure 2) and also poplar was transplanted into the surface layer (Figure 2). After transplanting, water was supplied through the bottom of each column for rootage until July and then prepared LM $(70 \mathrm{~L}$; $\mathrm{N}: 110 \mathrm{mg} \cdot \mathrm{L}^{-1} ; \mathrm{P}: 110 \mathrm{mg} \cdot \mathrm{L}^{-1}$ ) was supplied respectively from August to September in 2013 and from April to May in 2014 through the column bottom, using a water tank. Soil samples were collected from each sampling hole each year in April and September and in November 2014 and assessed for the effect of deep-planting technique on the removal of $\mathrm{N}$ and $\mathrm{P}$ in LM-applied soils. After cultivation, each column was split in half and then the root growth was investigated. 


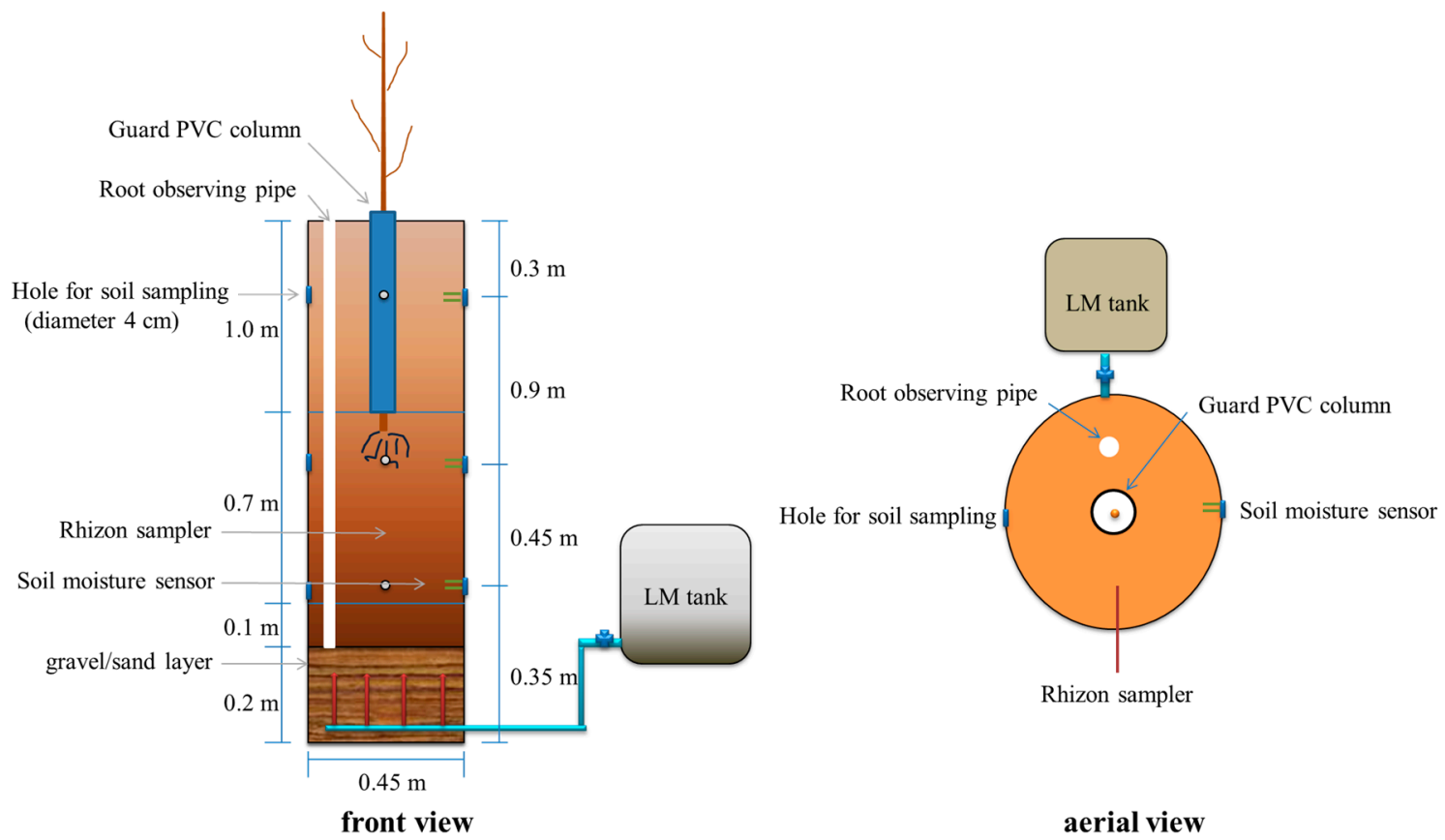

Figure 2. Schematic diagram of the pilot-scale column experiment.

\subsection{Analysis of Soil and Plant}

Soil: Prior to analysis, collected soil samples from the pot and pilot-scale column studies were air-dried and sieved to $<2 \mathrm{~mm}$ using a stainless steel sieve. Soil EC was determined in a soil:distilled water suspension (soil to water ratio, 1:5) using a EC meter (S230, Mettler Toledo, Greifensee, Switzerland) after one hour shaking. Total $\mathrm{N}$ in soils was determined from undigested dry samples using an elemental analyzer (CNS-2000, Leco, St. Joseph, MI, USA). Total P contents in soils were analyzed following acid digestion. Soil samples $(0.5 \mathrm{~g})$ were digested with concentrated $\mathrm{HNO}_{3}(5 \mathrm{~mL})$ using a block digester (OD-98-001, ODLAB, Seoul, Korea). The digested suspension was filtered through a $0.45 \mathrm{~mm}$ syringe filter and $\mathrm{P}$ contents in the filtrate were determined by the ascorbic acid method [19].

Plant: The collected leaves and branches were washed once with running tap water and then rinsed twice with distilled water. Samples were dried in a fan-forced oven at $70{ }^{\circ} \mathrm{C}$ for $72 \mathrm{~h}$. The dried woody plant sample was weighed, powdered prior to measurement of $\mathrm{N}$ and $\mathrm{P}$ contents. The $\mathrm{N}$ content in woody plant samples was determined from undigested dry samples using an elemental analyzer (CNS-2000, Leco, St. Joseph, MI, USA). The P concentration was measured via a UV-Spectrophotometer (Specord 200, Analytikjena, Jena, Germany) at $470 \mathrm{~nm}$ after the filtrate was mixed with ammonium molybdate and ammonium meta-vanadate according to the National Institute of Agricultural Sciences in Korea [20].

\subsection{Statistical Analysis}

All the experiments were conducted with three replications. For ease of visualization, the averages of triplicate determinations together with the standard deviation are presented in table and figures. Any significant differences amongst treatments were determined by ANOVA using SAS 9.3 software (SAS for Windows v. 9.3, SAS Institute Inc., Cary, NC, USA). 


\section{Results and Discussion}

\subsection{Pot Trial}

\subsubsection{Soil}

Since soil EC is one of the most useful and easily obtained properties of soil that influences plant productivity [21], it can be used to indirectly estimate the amount of inorganic ions such as $\mathrm{N}$ and $\mathrm{P}$ available for plant uptake. Soil EC values are presented Figure 3. Before the experiment, the collected soil EC value was $0.1 \mathrm{dS} \cdot \mathrm{m}^{-1}$ and there was not much change in soil EC observed when tap water was applied with/without plant cultivation for two years. Also, EC values of the soil after adding 1S LM without plant cultivation, were maintained in the range of 0.09 to $0.25 \mathrm{dS} \cdot \mathrm{m}^{-1}$ for two years. Water transfer from the soil-plant system to the atmosphere occurs through evapotranspiration, which includes evaporation of water from the soil and transpiration through plant stomata. Therefore, even though 1S LM was supplied to the pot soil from the bottom, the EC of control (no woody plant cultivation) soil was not influenced by 1S LM because less evapotranspiration is associated with the lack of moisture rising from bottom to top. However, though EC values of soils after LM application were not measured during the cultivation period in 2012, EC values of the soils after adding 1S LM with both poplar and willow cultivation dramatically increased by 379\% from April to July 2013. This was attributed to the enhanced evapotranspiration of water from applied LM caused by cultivation due to the major growing season for trees in Korea (from late spring to early autumn-late March to early September). Subsequently, soil EC values decreased back to original condition from July to December 2013 due to the uptake of inorganic ions by plants.

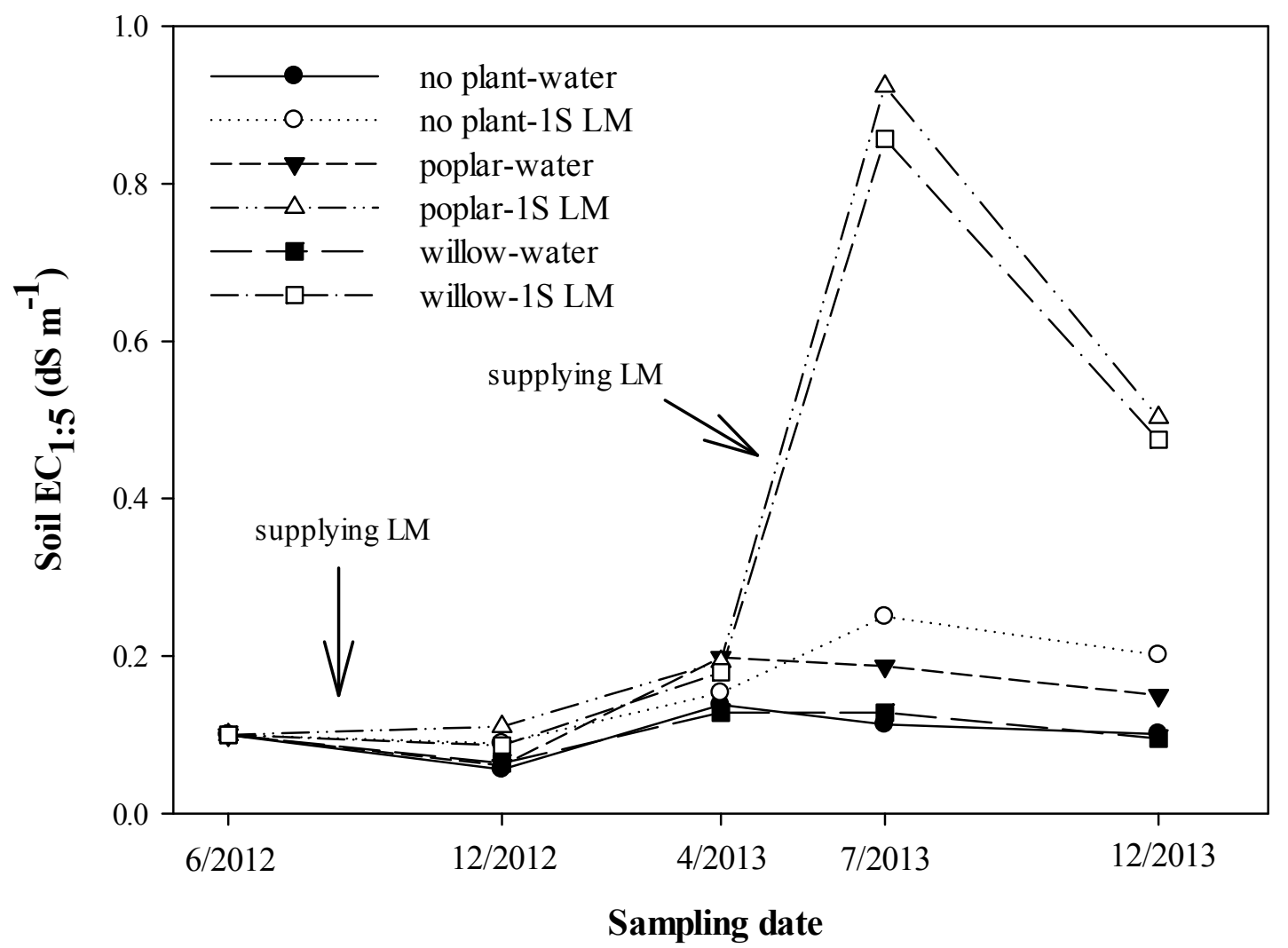

Figure 3. Variation in soil electrical conductivity $\left(\mathrm{EC}_{1: 5}\right)$ with sampling time for the different treatment regimes. LM: liquid manure; $1 \mathrm{~S}$ : full strength. 
The amounts of applied liquids for each treatment and the estimated and measured residual values of $\mathrm{N}$ and $\mathrm{P}$ in soil after harvest are given in Table 1. A higher amount of LM was applied to the cultivation pots than to the non-cultivation pots due to the already mentioned evapotranspiration. For this reason, it was expected that large amounts of $\mathrm{N}$ and $\mathrm{P}$ accumulated consistently in LM-applied soil with plant cultivation. In fact, when estimating the soil residual $\mathrm{N}$ and $\mathrm{P}$ contents after harvest in 2012, the accumulated N and P contents in 1S LM-applied soil with poplar cultivation were $65 \%$ and $24 \%$ higher than those without cultivation. However, contrary to expectations, the measured residual values of $\mathrm{N}$ and $\mathrm{P}$ in soil with $1 \mathrm{~S}$ LM application were similar with those in soil receiving tap water. These results can be explained by the uptake of contaminants by woody plants. The effective $\mathrm{N}$ and $\mathrm{P}$ removal by woody plants were supported well by the difference between estimated and measured $\mathrm{N}(\Delta \mathrm{N})$ and $\mathrm{P}(\Delta \mathrm{P})$ content in soils. For instance, in 2012, the $\Delta \mathrm{N}$ and $\Delta \mathrm{P}$ concentration in 1S LM-applied soil with willow cultivation were 2.52 and $0.74 \mathrm{~g} \cdot \mathrm{kg}^{-1}$ respectively, whereas those without cultivation were 0.09 and $0.02 \mathrm{~g} \cdot \mathrm{kg}^{-1}$ respectively. Also, in the woody plants-cultivated pots, elevated liquid manure application rate increased consistently both $\Delta \mathrm{N}$ and $\Delta \mathrm{P}$ contents. In 2012, the poplar and willow-cultivated soils with 1S LM application showed seven and 10 times higher $\Delta \mathrm{N}$, respectively, and four and five times higher $\Delta \mathrm{P}$, respectively, than tap water-applied soils, while $1 / 2 \mathrm{~S}$ LM-applied soil showed four and five times higher $\Delta \mathrm{N}$ content, respectively, and four and five times higher $\Delta \mathrm{P}$, respectively, than tap water-applied soil. This implied that woody plants used in this study had a much larger uptake capacity of $\mathrm{N}$ and $\mathrm{P}$ from the liquid manure. Poplar and willow were classified as fast-growing species [22] and the fast growth leads to rapid uptake of nutrients, and also heavy metals, from the soil [23]. For example, in China, poplar (Populus deltoides $\times$ Populus nigra) grown in Cd-contaminated purple soil and alluvial soil accumulate 542 and $577 \mathrm{~g} \cdot \mathrm{Cd}$ per plant and Cd concentration in poplar was increased with the increase of Cd concentration in both soils [24]. Also, similar decreases in $\mathrm{N}$ and $\mathrm{P}$ originated from contaminated sources have previously been reported following cultivation of poplar and willow [25]: poplar and willow grown in lysimeters are able to retain $66 \%$ and $82 \%$ respectively for total $\mathrm{N}$ and $80 \%$ and $99 \%$ respectively for total $\mathrm{P}$, following the application of landfill leachate containing $378 \mathrm{~kg} \cdot \mathrm{N} \cdot \mathrm{ha}^{-1} \cdot \mathrm{year}^{-1}$ and $19 \mathrm{~kg} \cdot \mathrm{P} \cdot \mathrm{ha}^{-1} \cdot \mathrm{year}^{-1}$. 
Table 1. The amounts of applied liquids, estimated and measured nitrogen $(\mathrm{N})$ and phosphorous $(\mathrm{P})$ contents in soils, and the difference between both estimated and measured $\mathrm{N}(\Delta \mathrm{N})$ and $\mathrm{P}(\Delta \mathrm{P})$ contents in soils.

\begin{tabular}{|c|c|c|c|c|c|c|c|c|}
\hline & Treatments & $\begin{array}{l}\text { Amounts of Applied Liquids } \\
\text { (L) }\end{array}$ & $\begin{array}{c}\text { Estimated N } \\
\left(\mathrm{g} \cdot \mathrm{kg}^{-1}\right)\end{array}$ & $\begin{array}{c}\text { Estimated P } \\
\left(\mathrm{g} \cdot \mathrm{kg}^{-1}\right)\end{array}$ & $\begin{array}{c}\text { Measured N } \\
\left(\mathrm{g} \cdot \mathrm{kg}^{-1}\right)\end{array}$ & $\begin{array}{c}\text { Measured P } \\
\left(\mathrm{g} \cdot \mathrm{kg}^{-1}\right)\end{array}$ & $\Delta \mathbf{N}$ & $\Delta \mathbf{P}$ \\
\hline \multicolumn{9}{|c|}{2012} \\
\hline \multirow{3}{*}{ No plant } & water & $15.3 \pm 4.0$ & $1.0 \pm 0.0$ & $0.9 \pm 0.0$ & $0.7 \pm 0.1$ & $0.8 \pm 0.1$ & 0.3 & 0.1 \\
\hline & $1 / 2 S$ liquid manure & $13.5 \pm 1.6$ & $1.3 \pm 0.0$ & $1.0 \pm 0.0$ & $0.7 \pm 0.2$ & $0.7 \pm 0.0$ & 0.7 & 0.3 \\
\hline & 1S liquid manure & $13.2 \pm 2.0$ & $1.7 \pm 0.1$ & $1.1 \pm 0.0$ & $0.7 \pm 0.1$ & $0.8 \pm 0.0$ & 0.9 & 0.3 \\
\hline \multirow{3}{*}{ Poplar } & water & $33.0 \pm 2.3$ & $1.0 \pm 0.0$ & $0.9 \pm 0.0$ & $0.7 \pm 0.2$ & $0.8 \pm 0.1$ & 0.3 & 0.1 \\
\hline & $1 / 2 S$ liquid manure & $34.1 \pm 2.0$ & $1.9 \pm 0.0$ & $1.1 \pm 0.0$ & $0.7 \pm 0.1$ & $0.7 \pm 0.0$ & 1.1 & 0.4 \\
\hline & 1S liquid manure & $34.6 \pm 0.5$ & $2.7 \pm 0.0$ & $1.3 \pm 0.0$ & $0.8 \pm 0.1$ & $0.8 \pm 0.0$ & 2.0 & 0.5 \\
\hline \multirow[t]{3}{*}{ Willow } & water & $38.0 \pm 6.5$ & $1.0 \pm 0.0$ & $0.9 \pm 0.0$ & $0.8 \pm 0.1$ & $0.8 \pm 0.1$ & 0.2 & 0.1 \\
\hline & $1 / 2 S$ liquid manure & $34.4 \pm 1.1$ & $1.9 \pm 0.0$ & $1.1 \pm 0.0$ & $0.9 \pm 0.0$ & $0.8 \pm 0.0$ & 1.0 & 0.3 \\
\hline & 1S liquid manure & $35.4 \pm 3.0$ & $2.8 \pm 0.2$ & $1.3 \pm 0.0$ & $0.8 \pm 0.1$ & $0.8 \pm 0.1$ & 2.0 & 0.5 \\
\hline \multicolumn{9}{|c|}{2013} \\
\hline \multirow{3}{*}{ No plant } & water & $4.0 \pm 1.4$ & $2.9 \pm 0.0$ & $0.6 \pm 0.0$ & $3.0 \pm 0.0$ & $0.6 \pm 0.0$ & -0.1 & 0.0 \\
\hline & $1 / 2 S$ liquid manure & $2.8 \pm 0.4$ & $3.0 \pm 0.0$ & $0.7 \pm 0.1$ & $2.9 \pm 0.0$ & $0.6 \pm 0.1$ & 0.0 & 0.0 \\
\hline & 1S liquid manure & $3.3 \pm 0.4$ & $3.1 \pm 0.0$ & $0.7 \pm 0.0$ & $3.0 \pm 0.0$ & $0.7 \pm 0.0$ & 0.1 & 0.0 \\
\hline \multirow[t]{3}{*}{ Poplar } & water & $77.2 \pm 4.6$ & $2.9 \pm 0.1$ & $0.5 \pm 0.1$ & $3.0 \pm 0.0$ & $0.6 \pm 0.1$ & -0.1 & 0.0 \\
\hline & $1 / 2 S$ liquid manure & $46.0 \pm 3.1$ & $4.0 \pm 0.1$ & $1.0 \pm 0.0$ & $3.0 \pm 0.0$ & $0.9 \pm 0.0$ & 0.9 & 0.1 \\
\hline & 1S liquid manure & $41.5 \pm 4.0$ & $4.9 \pm 0.2$ & $1.3 \pm 0.1$ & $3.5 \pm 0.1$ & $0.8 \pm 0.1$ & 1.4 & 0.5 \\
\hline \multirow[t]{3}{*}{ Willow } & water & $39.0 \pm 1.4$ & $3.0 \pm 0.1$ & $0.7 \pm 0.1$ & $3.0 \pm 0.1$ & $0.6 \pm 0.1$ & 0.0 & 0.0 \\
\hline & $1 / 2 S$ liquid manure & $49.4 \pm 4.9$ & $3.8 \pm 0.6$ & $0.9 \pm 0.2$ & $3.0 \pm 0.2$ & $0.8 \pm 0.1$ & 0.7 & 0.1 \\
\hline & 1S liquid manure & $73.9 \pm 4.4$ & $6.4 \pm 0.1$ & $1.8 \pm 0.1$ & $3.9 \pm 0.1$ & $1.1 \pm 0.1$ & 2.5 & 0.7 \\
\hline
\end{tabular}

1S: full strength liquid manure; $1 / 2 \mathrm{~S}$ : half strength liquid manure (LM:water $=1: 1$ ). 


\subsubsection{Plant}

Compared to the application of tap water, application of 1/2S LM significantly increased the aboveground biomass yield (dry weight) of both poplar and willow which was attributed to nutrients (N, P and nutrient salts) released from LM (Figure 4). For instance, the biomass of the poplar and willow cultivated for two years irrigated with $1 / 2$ S LM were $43 \%$ and $30 \%$ respectively higher than those receiving tap water. However biomass of both woody plants grown in 1S LM-treated soil were not significantly different from those in tap water-treated soil. This was due to the accumulation of salts in soils following 1S LM treatment. Excess salt induces ionic and osmotic stresses that disturb metabolism and lead to reduction of plant development [26,27]. For example, Chen et al. [28] reported that poplar (P. popularis) exhibited a clear symptom of salt damage such as abscission of leaves after 15 days of exposure to saline $(300 \mathrm{mM} \mathrm{NaCl})$ treatment. In agreement with this previous study, during woody plants cultivation, leaf abscission was observed in woody plants grown in 1S LM-treated soil. However, it is expected that if plants are grown in field area, the plant damage is reduced by sufficient rootage.

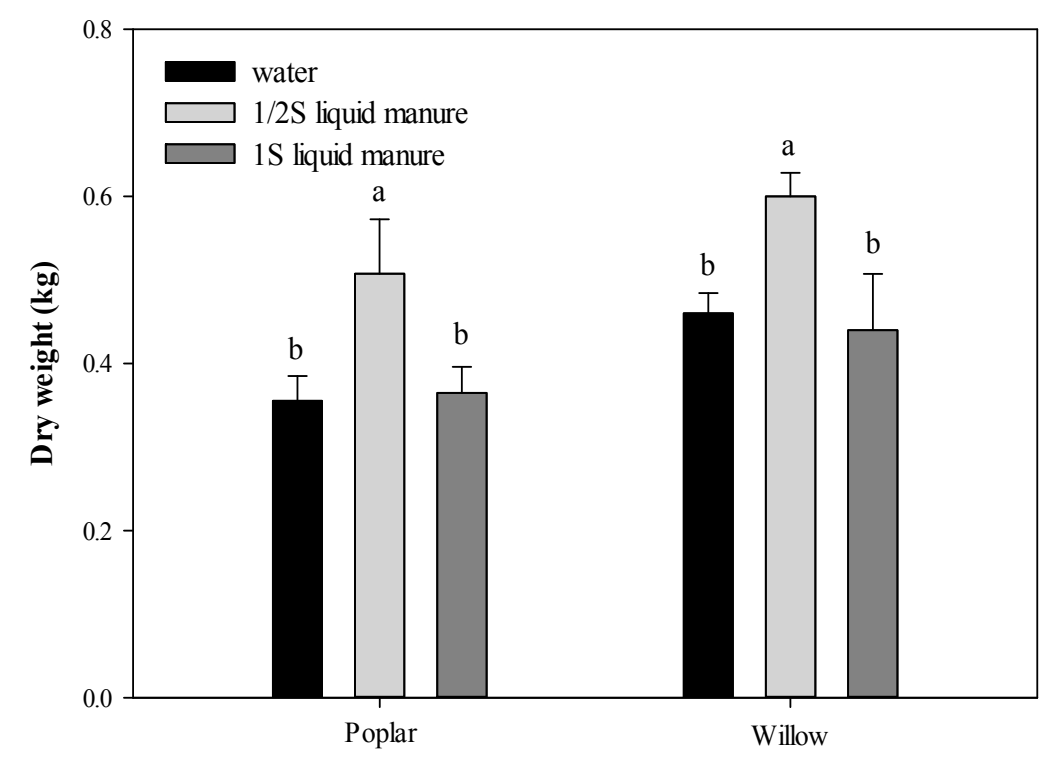

Figure 4. Shoot dry weight of the woody plants cultivated in pots. Columns assigned with different letters indicate significant differences $(p<0.05)$ amongst the treatments.

Even though there were no significant differences in biomass yield of both woody plants between 1S LM application and tap water application, as expected from the observed increase in soil $\Delta \mathrm{N}$ and $\Delta \mathrm{P}$ concentrations following woody plants cultivation, the concentration of $\mathrm{N}$ and $\mathrm{P}$ in the leaves of both the woody plants increased with elevated LM application rate (Figure 5). The concentrations of $\mathrm{N}$ and $\mathrm{P}$ in the leaves of poplar cultivated in the soil receiving 1S LM were $49 \mathrm{~g} \cdot \mathrm{kg}^{-1}$ and $2.0 \mathrm{~g} \cdot \mathrm{kg}^{-1}$ respectively, compared to $8 \mathrm{~g} \cdot \mathrm{kg}^{-1}$ and $1.2 \mathrm{~g} \cdot \mathrm{kg}^{-1}$ respectively when grown in the soil receiving tap water. Also $\mathrm{N}$ and P contents in the willow leaves cultivated in 1S LM-applied soil were $43 \mathrm{~g} \cdot \mathrm{kg}^{-1}$ and $2.3 \mathrm{~g} \cdot \mathrm{kg}^{-1}$ respectively which was four and two times higher respectively than that in the willow leaves from the tap water-applied soil $\left(\mathrm{N}: 11 \mathrm{~g} \cdot \mathrm{kg}^{-1} ; \mathrm{P}: 1.5 \mathrm{~g} \cdot \mathrm{kg}^{-1}\right)$. As a result, these results clearly demonstrate that both poplar and willow had a sufficient nutrients removal efficiency and did aid in the remediation of $\mathrm{N}$ and $\mathrm{P}$ contaminated soil. In other words, these woody plants could promote the removal of $\mathrm{N}$ and $\mathrm{P}$ originating from the carcass burial sites during growth. 



Figure 5. $\mathrm{N}$ and $\mathrm{P}$ contents in the woody plants cultivated in pots. Columns assigned with different letters indicate significant differences $(p<0.05)$ amongst the treatments.

\subsection{Pilot-Scale Column Experiment}

\subsubsection{Soil}

In order to evaluate the efficiency of phytoremediation while using deep-planting techniques, EC and contaminants ( $\mathrm{N}$ and $\mathrm{P}$ ) concentrations in both surface and deep-planted soil samples were compared, and consequently these properties in soil are influenced by planting depth. When poplar was cultivated on surface layer, soil $\mathrm{EC}_{1: 5}$ at 1 and $1.5 \mathrm{~m}$ depths were maintained between $0.05 \sim 0.08 \mathrm{dS} \cdot \mathrm{m}^{-1}$ and $0.06 \sim 0.1 \mathrm{dS} \cdot \mathrm{m}^{-1}$ respectively during the cultivation period (Figure 6). However, the EC in both poplar and willow planted soils using deep planting technique were 0.24 and $0.21 \mathrm{dS} \cdot \mathrm{m}^{-1}$, respectively, in September, 2013 , which were 0.14 and $0.11 \mathrm{dS} \cdot \mathrm{m}^{-1}$ higher than that observed during April 2013 (Figure 6). This was attributed to the applied LM transfer from the deep soil layers to rhizosphere via deep-planted root system. Moreover, like the pot study, these soils' EC decreased back to original condition due to the ion uptake by deep-planted roots of woody plants. Similar results were also observed for $\mathrm{N}$ and $\mathrm{P}$ (Figure 7). The $\mathrm{N}$ and $\mathrm{P}$ contents at each depth in surface planted soil showed a slight change during cultivation period. However, the N and P contents in soils collected at $1.5 \mathrm{~m}$ were strongly affected by deep-planting of woody plants. For instance, after first LM application, $\mathrm{N}$ contents in deep-planted soils at $1.5 \mathrm{~m}$ depth increased by $63 \%$ and $55 \%$ from April to September and then decreased from $1.8 \sim 2 \mathrm{~g} \cdot \mathrm{kg}^{-1}$ to $1.6 \mathrm{~g} \cdot \mathrm{kg}^{-1}$ between September 2013 and November 2014. Again, there was then an increase followed by a decrease in the contents of $\mathrm{N}$ after second LM application. Also, P contents in deep-planted soils at $1.5 \mathrm{~m}$ depth increased from $0.5 \mathrm{~g} \cdot \mathrm{kg}^{-1}$ in April, 2013 to $0.7 \sim 0.8 \mathrm{~g} \cdot \mathrm{kg}^{-1}$ in April 2014 and then decreased to a similar level as those in the surface planted soil. 




Sampling date

Figure 6. Changes in $\mathrm{EC}_{1: 5}$ in soils at $1 \mathrm{~m}$ and $1.5 \mathrm{~m}$ depth (SP: surface planted poplar; DP: deep-planted poplar; DW: deep-planted willow, supplying LM means the event of application of liquid manure).
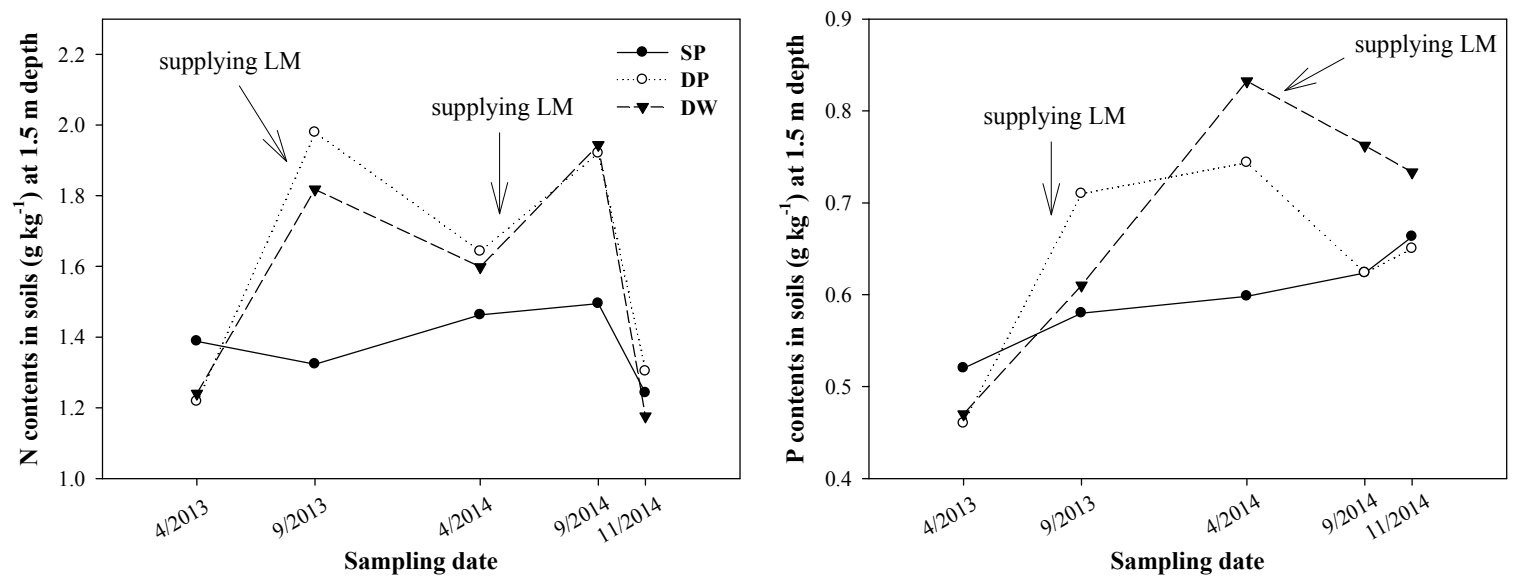

Figure 7. Changes in $\mathrm{N}$ and $\mathrm{P}$ contents in soil at $1.5 \mathrm{~m}$ depth (SP: surface planted poplar; DP: deep-planted poplar; DW: deep-planted willow, supplying LM means the event of application of liquid manure).

\subsubsection{Plant}

As described above, deep-planted poplar and willow transferred the contaminant from deep soil layer to their rhizosphere. This was due to the fact that both poplar and willow had long stems and consequently, they can survive and take up $\mathrm{N}$ and $\mathrm{P}$ from more depth in the contaminated soils even though they were buried deeply (up to stem height). Indeed, an increased number of root hairs of deep-planted poplar and willow were observed by endoscopy at $1.5 \mathrm{~m}$ depth in October 2013, which 
was not the case for surface planted poplar (Figure 8). Furthermore, results of observation of root growth after cultivation showed that the deep-planted woody plant roots reached a depth of two meters, which corresponds with the depth of carcass burial sites in Korea. While the surface planted woody plant roots reached only a depth of $1 \mathrm{~m}$ (Figure 9). Thus, these results demonstrated that the deep-planted poplar and willow roots could more readily access the deeper contaminated plume and enable more efficient uptake of the amount of contaminants from deep soil layers.

In general, phytoremediation requires contaminants to be in contact with the root zone of the plants. Either the contaminant(s) must be within the plant's root zone, or move to be within the range of the plants $[29,30]$. However, some contaminated plume, such as leachate released from carcass burial sites, may be too deep for plant roots to reach and penetrate. For this reason, the deep-planting technique using poplar and willow can be used in order to solve this problem.
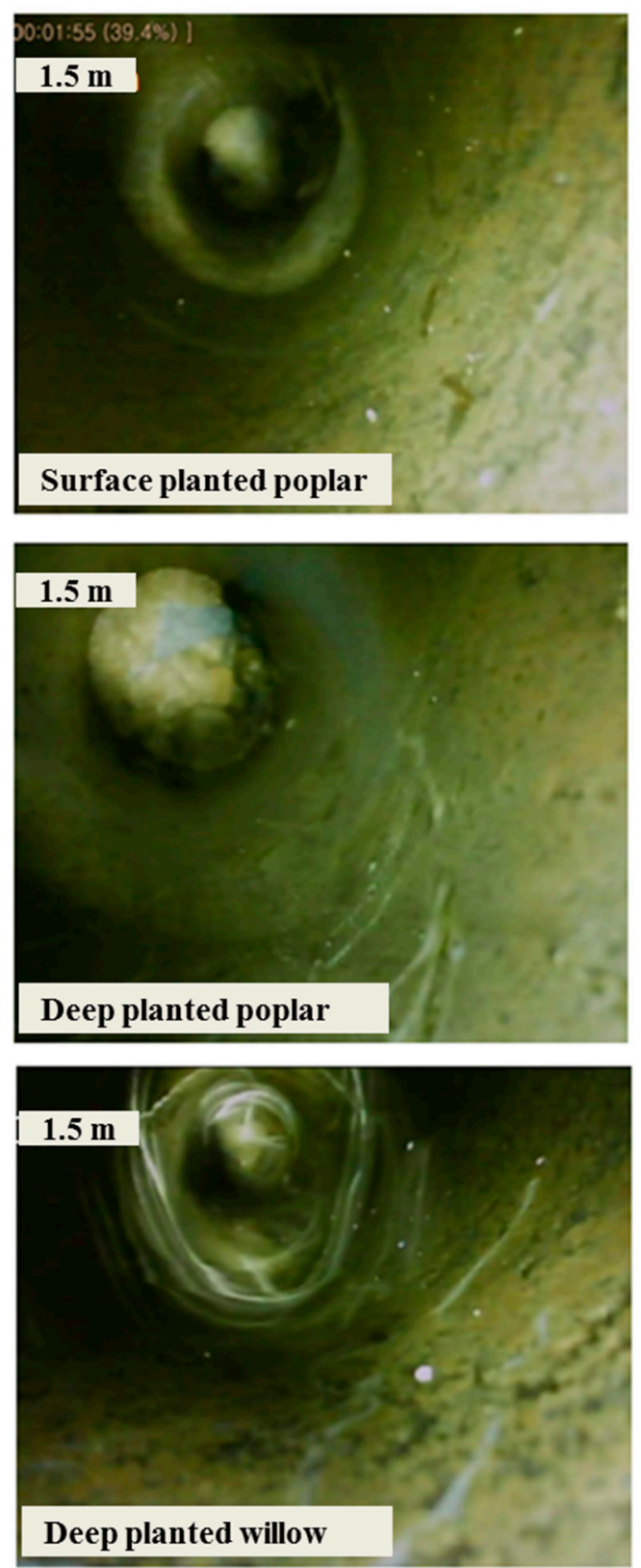

Figure 8. Root growth of woody plants observed through endoscopy at $1.5 \mathrm{~m}$ depth in October 2013. 

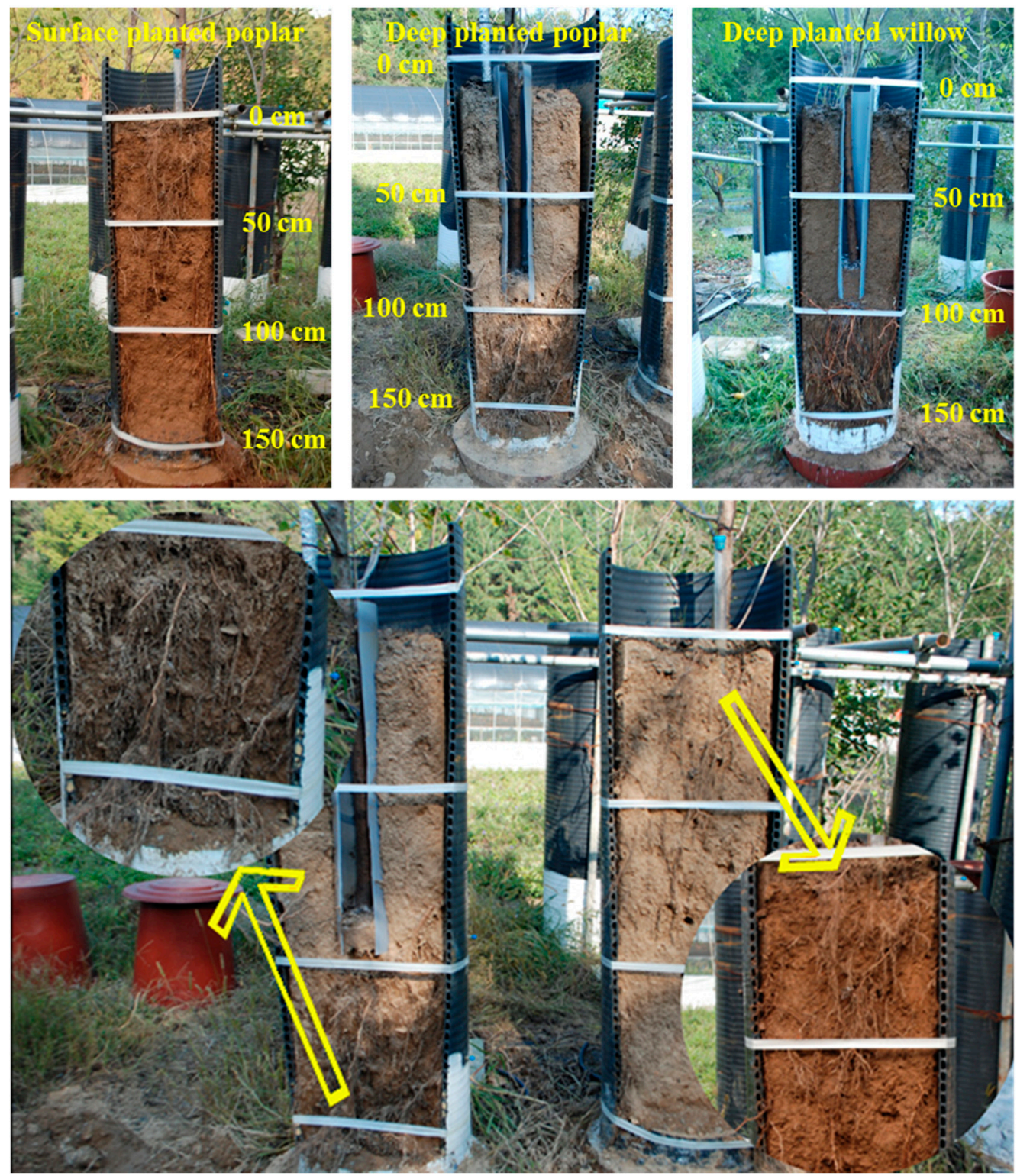

Figure 9. Root growth of woody plants after grown with surface planting and deep-planting with guard column.

\section{Conclusions}

The current study shows that through the adoption of the deep-planting technique, both poplar and willow could not only rapidly and effectively transfer N and P in LM from the deep soil layers to the rhizosphere, but can also take up large amounts of $\mathrm{N}$ and $\mathrm{P}$ from deep soil layers. This was possibly due to the fact that, firstly, both the poplar and willow could remove $\mathrm{N}$ and $\mathrm{P}$ from soil affected by contaminated plume effectively, and secondly, both poplar and willow have enough a long stem to bury more deeply into the soil. Therefore, deep-planting technique using long stem woody plants such as poplar and willow can be a useful technology for the removal of contaminants such as $\mathrm{N}$ and $\mathrm{P}$ originating from the livestock burial sites. Furthermore, the concept of deep-planting technique for the enhanced phytoremediation of carcass burial sites as proposed in this study would help in the successful remediation of contaminants even up to a depth of about two meters compared to typical phytoremediation technology. 
Acknowledgments: This study was supported by Korea Ministry of Environment as the GAIA Project (Project No. 2012000560004).

Author Contributions: All the authors contributed to the conception and development of this work and approved the final version of the manuscript.

Conflicts of Interest: The authors declare no conflict of interest.

\section{References}

1. Choi, J.W.; Kim, J.Y.; Nam, Y.J.; Lee, W.S.; Han, J.S. Comparison of compositional characteristics of amino acids between livestock wastewater and carcass leachate. Environ. Monit. Assess. 2013, 185, 9413-9418. [CrossRef] [PubMed]

2. Kim, G.H.; Pramanik, S. Biosecurity procedures for the environmental management of carcasses burial sites in Korea. Environ. Geochem. Health 2016, 38, 1229-1240. [CrossRef] [PubMed]

3. Kim, K.H.; Kim, K.R.; Kim, H.S.; Lee, G.T.; Lee, K.H. Assessment of soil and groundwater contamination at two animal carcass disposal sites. Korean J. Soil Sci. Fertil. 2010, 43, 384-389. (In Korean)

4. Meagher, R.B. Phytoremediation of toxic elemental and organic pollutants. Curr. Opin. Plant Biol. 2000, 3, 153-162. [CrossRef]

5. Alkorta, I.; Garbisu, C. Phytoremediation of organic contaminants in soils. Bioresour. Technol. 2001, 79, 273-276. [CrossRef]

6. Ali, H.; Khan, E.; Sajad, M.A. Phytoremediation of heavy metals-Concepts and applications. Chemosphere 2013, 91, 869-881. [CrossRef] [PubMed]

7. Pilon-Smits, E. Phytoremediation. Annu. Rev. Plant Biol. 2005, 56, 15-39. [CrossRef] [PubMed]

8. Licht, L.A.; Isebrands, J.G. Linking phytoremediated pollutant removal to biomass economic opportunities. Biomass Bioenergy 2005, 28, 203-218. [CrossRef]

9. Pietrini, F.; Iori, V.; Bianconi, D.; Mughini, G.; Massacci, A.; Zacchini, M. Assessment of physiological and biochemical responses, metal tolerance and accumulation in two eucalypt hybrid clones for phytoremediation of cadmium-contaminated waters. J. Environ. Manag. 2015, 162, 221-231. [CrossRef] [PubMed]

10. Zárubová, P.; Hejcman, M.; Vondráčková, S.; Mrnka, L.; Száková, J.; Tlustoš, P. Distribution of P, K, Ca, Mg, $\mathrm{Cd}, \mathrm{Cu}, \mathrm{Fe}, \mathrm{Mn}, \mathrm{Pb}$ and $\mathrm{Zn}$ in wood and bark age classes of willows and poplars used for phytoextraction on soils contaminated by risk elements. Environ. Sci. Pollut. Res. 2015, 22, 18801-18813. [CrossRef] [PubMed]

11. Fischerová, Z.; Tlustoš, P.; Száková, J.; Šichorová, K. A comparison of phytoremediation capability of selected plant species for given trace elements. Environ. Pollut. 2006, 144, 93-100. [CrossRef] [PubMed]

12. Barac, T.; Weyens, N.; Oeyen, L.; Taghavi, S.; van der Lelie, D.; Dubin, D.; Spliet, M.; Vangronsveld, J. Field note: Hydraulic containment of a BTEX plume using poplar trees. Int. J. Phytorem. 2009, 11, 416-424. [CrossRef] [PubMed]

13. Jensen, J.K.; Holm, P.E.; Nejrup, J.; Larsen, M.B.; Borggaard, O.K. The potential of willow for remediation of heavy metal polluted calcareous urban soils. Environ. Pollut. 2009, 157, 931-937. [CrossRef] [PubMed]

14. Migeon, A.; Richaud, P.; Guinet, F.; Chalot, M.; Blaudez, D. Metal accumulation by woody species on contaminated sites in the north of France. Water Air Soil Pollut. 2009, 204, 89-101. [CrossRef]

15. Hu, Y.; Nan, Z.; Su, J.; Wang, N. Heavy metal accumulation by poplar in calcareous soil with various degrees of multi-metal contamination: Implications for phytoextraction and phytostabilization. Environ. Sci. Pollut. Res. 2013, 20, 7194-7203. [CrossRef] [PubMed]

16. Salido, A.L.; Hasty, K.L.; Lim, J.M.; Butcher, D.J. Phytoremediation of arsenic and lead in contaminated soil using Chinese brake ferns (Pteris vittata) and Indian mustard (Brassica juncea). Int. J. Phytorem. 2003, 5, 89-103. [CrossRef] [PubMed]

17. Tangahu, B.V.; Abdullah, S.R.S.; Basri, H.; Idris, M.; Anuar, N.; Mukhlisin, M. A review on heavy metals (As, $\mathrm{Pb}$, and $\mathrm{Hg}$ ) uptake by plants through phytoremediation. Int. J. Chem. Eng. 2011, 2011, 939161. [CrossRef]

18. Dreesen, D.R.; Fenchel, G.A. Deep-planting techniques to establish riparian vegetation in arid and semiarid regions. Nativ. Plants J. 2010, 11, 15-22. [CrossRef]

19. Kuo, O. Phosphorus. In Methods of Soil Analysis. Part 3. Chemical Methods. SSSA Book Series 5; Sparks, D.L., Page, A.L., Helmke, P.A., Loeppert, R.H., Soltanpour, P.N., Tabatabai, M.A., Johnson, C.T., Sumner, M.E., Eds.; SSSA/ASA: Madison, WI, USA, 1993; pp. 869-919. 
20. National Institute of Agricultural Science (NIAS). Method of Soil and Plant Analysis; Rural Development Administration: Suwon, Korea, 2000. (In Korean)

21. Corwin, D.L.; Lesch, S.M. Application of soil electrical conductivity to precision agriculture. Agron. J. 2003, 95, 455-471. [CrossRef]

22. Rytter, R.M. The potential of willow and poplar plantations as carbon sinks in Sweden. Biomass Bioenergy 2012, 36, 86-95. [CrossRef]

23. Pulford, I.D.; Watson, C. Phytoremediation of heavy metal-contaminated land by trees-a review. Environ. Int. 2003, 29, 529-540. [CrossRef]

24. Wu, F.; Yang, W.; Zhang, J.; Zhou, L. Cadmium accumulation and growth responses of a poplar (Populus deltoides $\times$ Populus nigra) in cadmium contaminated purple soil and alluvial soil. J. Hazard. Mater. 2010, 177, 268-273. [CrossRef] [PubMed]

25. Dimitriou, I.; Aronsson, P. Landfill leachate treatment with willows and poplars-Efficiency and plant response. Waste Manag. 2010, 30, 2137-2145. [CrossRef] [PubMed]

26. Zhu, J.K. Plant salt tolerance. Trends Plant Sci. 2001, 6, 66-71. [CrossRef]

27. Munns, R. Comparative physiology of salt and water stress. Plant Cell Environ. 2002, 25, 239-250. [CrossRef] [PubMed]

28. Chen, S.; Li, J.; Fritz, E.; Wang, S.; Hüttermann, A. Sodium and chloride distribution in roots and transport in three poplar genotypes under increasing $\mathrm{NaCl}$ stress. For. Ecol. Manag. 2002, 168, 217-230. [CrossRef]

29. Environmental Protection Agency: Introduction to Phytoremediation. Available online: https//www.Nepis. epa.gov/Exe/ZyPURL.cgi?Dockey=30003T7G.TXT (accessed on 1 October 2016).

30. Khan, A.G.; Kuek, C.; Chaudhry, T.M.; Khoo, C.S.; Hayes, W.J. Role of plants, mycorrhizae and phytochelators in heavy metal contaminated land remediation. Chemosphere 2000, 41, 197-207. [CrossRef]

(C) 2017 by the authors; licensee MDPI, Basel, Switzerland. This article is an open access article distributed under the terms and conditions of the Creative Commons Attribution (CC BY) license (http:/ / creativecommons.org/licenses/by/4.0/). 